\title{
Anna Ziębińska-Witek: Muzealizacja komunizmu w Polsce i Europie Środkowo- W schodniej [The Musealisation of Communism in Poland and Central and Eastern Europe], (Lublin: Wydawnictwo UMCS, 2018), 341 pp. ISBN: 978-83-227-9149-3, photographs.
}

\section{Anna Ziębińska-Witek's critical approach to the musealisation of communism}

\author{
Izabela Skórzyńska
}

Izabela Skórzyńska

Prof. UAM dr hab. (associate professor)

Adam Mickiewicz University in Poznań

Department of History

Uniwersytetu Poznańskiego 7 str.

64-614 Poznań

Poland

e-mail: indygo@amu.edu.pl

Anna Ziębinska-Witek: Murealizacja komunizmu w Polsce i Europie Środkowo-W schodniej...

What do we learn about communism while studying its museums? Do the musealisations of communism make it an experience similar to the museological study of other regimes or an experience which is exceptional? How do contemporary musealisations shed light and how do they obscure sight of the experiences of communism of the inhabitants of Central and Eastern Europe? Are these experiences identical or different, from the point of view of the museums of communism in the various places of Central and Eastern Europe where communism was installed and where it is today musealised? Anna Ziębińska-Witek answers such questions in her latest work, entitled The Musealisation of Communism in Poland and Central and Eastern Europe [Muzealizacja komunizmu w Polsce i Europie Środkowo-Wschodniej]. After reading this work I have to express my appreciation for its author, as well as undertaking some discussion on communism, which, even if belonging to the past, has not disappeared completely and which, studied by historians, still arouses extreme emotions in both its witnesses and heirs.

Keywords: Musealisation of Communism, Poland, Central and Eastern Europe, Politics of History and Memory

\section{Introduction}

The latest book of Anna Ziębińska-Witek once again shows us that we are dealing with an author using her extensive competences in the field of museum culture studies acquired as a result of many years of research ${ }^{1}$ to analyse the practices of museums presenting communism. With this work Ziębińska-Witek also proves herself to be an author with sound theoretical background, skilled in making pertinent systematisations of research material on account of

\footnotetext{
${ }^{1}$ So far, the scientific works of Anna Ziębińska-Witek have focused on issues related to the presentation of the past, including museums/musealisation relating to the Holocaust. I refer here to her two publications: Holocaust: Issues of Presentation (2005) a book on the representation crisis in the context of trauma as an inseparable element of the Holocaust and attempts to overcome this crisis in historiography, literature, and film, and History in Museums: Study on the Exposition of the Holocaust (2011) dedicated to selected Holocaust museums in Poland and abroad.
} 
both its specifics and the related theoretical concepts and categories, which she successfully uses to describe, analyse, and interpret the data obtained in the course of her research. ${ }^{2}$

The author begins by providing a comprehensive explanation of how she understands musealisation as the ongoing institutionalisation of the past culminating in a modern museum as a reaction to curb the continuity of the past and satisfying a need to maintain the legacy of this past for posterity. In this meaning, musealisation, according to Ziębińska-Witek, is a "conceptual separation and anchorage of a specific element from its natural context, incorporating [it] into a new, artificial context of a museum and an exhibition, in a new relationship with the place and other objects". "The separation of a specific element from its natural environment in order to incorporate it into the artificial context of a museum is a complex process of saving, and also establishing, a legacy of the past by historicising its footprints as particularly important for the community. ${ }^{4}$ The saving or establishing of the legacy of the past for posterity fulfils, as the author of Musealisation... points out, the four objectives of contemporary museums, namely the cognitive, aesthetic, educational, and political ones. ${ }^{5}$ These objectives are strictly interrelated, and the aesthetic disposition of objects/historical content in a museum organises a historical, political, and axiological framework for its activities and, as such, stimulates the production of knowledge, influencing the emotions and imagination of the audience and shaping their identity. ${ }^{6}$ Musealisation is, therefore, as Ziębińska-Witek rightly notes, a complex social practice being the result of competing and/or mutually supportive "knowledge, power, and ideology". 7

\footnotetext{
${ }^{2}$ The list of investigated museums is impressive and is divided according to different models for the museums of communism proposed by Ziębińska-Witek. Among them are: (1) the "national branding" model as exemplified by the European Solidarity Centre in Gdańsk, 1956 and the Uprising Museum in Poznań; (2) the "double occupation" model as exemplified by the Terror Háza in Budapest, and the museums of occupation and liberation in Vilnius, Riga, or Tallin; (3) the "patchwork identity" model as exemplified by the History Centre Zajezdnia in Wrocław, the Dialogue Centre Przełomy in Szczecin, and the House of European History in Brussels; (4) the "martyrological and hagiographic" model as exemplified by the Chamber of Memoryof Wujek Mine in Katowice and the Museum of Priest Jerzy Popieluszko in Warsaw; (5) the model of "exorcisms against communism" as exemplified by the National Museum of Romanian History and the Romanian Peasant Museum in Bucharest, and The Memorial of the Victims of Communism and of the Resistance in Sighet, Romania; (6) the model of "genocide museums" as exemplified by the Vilnius Museum of Genocide Victims; (7) the model of "the everyday life of special services" as exemplified by the Stasi Museum of Germany in Berlin and Dresden, and the KGB Museum-Viru Hotell in Tallin; (8) the "nostalgic" model as exemplified by the PRL Museum, Poland—Ruda Ślaska the Museum of Life under Communism, Poland-Warsaw, the DDR Museum, Germany-Berlin, and the State Agricultural Farm Museum Poland-Bolegorzyn; and (9) the model of "unwanted heritage"—communist monuments being sent to museums as in Ruda Ślaska where there is a park of them, to Kozłówka where there is a gallery of the communist art, or their display being executed in situ as with Feliks Dzierżyński's monument in Warsaw and the monuments of Soviet liberators in the former countries of the Eastern bloc.

${ }^{3}$ ZIĘBIŃSKA-WITEK, Anna. Murealizacja komunizmu w Polsce i Europie Środkowo-Wschodniej [Musealisation of Communism in Poland and Central and Eastern Europe], Lublin: Wydawnictwo UMCS, p. 19.

${ }^{4}$ ZIĘBIŃSKA-WITEK, Mužealizacja komunizmu..., pp. 19-20; SKÓRZYŃSKA, Izabela. Widowiska pržesžtości. Alternatywne polityki pamięci 1989-2009 [Performances of the Past: Alternative Politics of Memory in Poland 19892009]. Poznań: Instytut Historii UAM, 2010, pp. 28-29; SZPOCIŃSKI, Andrzej. Tworzenenie pržestrženi bistorycznej jako odpowiedź na nostalgie [Creating Historical Space as a Response to Nostalgia]. In: Kultura Wspótczesna, 2004/1, p. 61.

5 ZIĘBIŃSKA-WITEK, Muzealizacja komunizmu..., p. 16; POPCZYK, Maria. Estetyczne przestrzenie eksposygi muzealnych [Aesthetic Spaces of Museum Exhibitions]. Kraków: Universitas, 2008, p. 16.

${ }^{6}$ SKÓRZYŃSKA, Izabela. Mureum historyczne: teatr - widowisko, aktor - swiadek [Historical Museum: TheatrePerformance, Actor-Witness]. In: Historia Polski Od-nowa. Nowe narracje historii i muzealne reprezentacje pržesžtości [Polish History Re-New: New Narrations of History and Museum Representations of the Past]. Eds. R. Kostro, K. Wóycicki, M. Wysocki, Warsaw: Muzeum Historii Polski, 2014, pp. 88-89; POPCZYK, Estetyczne przestrzenie..., p. 16. ${ }^{7}$ ZIĘBIŃSKA-WITEK, Muzealizacja komunizmu..., p. 16.
} 
In this context, deeper relations between museum expositions with the history of historians and the presence of their history in museums, especially museums of communism, which belongs to history as long as it lives in the memory of its witnesses, are of particular importance and are still heavily debated by researchers. Moreover, no one needs to be convinced that thirty years after the fall of communism, despite its abundant historiography, knowledge on communism remains incomplete, and the interpretation of this knowledge has given rise to numerous disputes and arguments. Meanwhile, museums of communism, although drawing on historiography, also follow other orders than academic knowledge. In the 1980s, according to Ziębińska-Witek, when new museology was starting to develop in the world, the museum became a part of public history. ${ }^{8}$ Museums established on this wave soon found a new ally in the form of modern media, which contributed to their mediatisation, and narrativisation. ${ }^{9}$ As a result, Ziębińska-Witek continues, museology has been assigned a new task of "developing the interests of the public and making plans for the future, taking into account the forces driving the development of societies". ${ }^{10}$ The claim of this "sensitive" museum, along with "perceiving historical expositions as a reflection of the autoimage of a nation/group, that is how certain communities want to be perceived 'outside', while maintaining the museum's authority as a carrier of certain historical knowledge", 11 determined its ambiguous condition-a staging of knowledge and power, aesthetics, and politics, from which the authorities, in particular, began to draw benefits. Hence the hypothesis of the author of Musealisation... that contemporary museums of communism operate at "the crossroads of discourses on memory, history and legacy, are the products of the present and instruments of historical politics, and equally exhibit and hide fragments of the past; furthermore, the histories presented in these museums reinforce or legitimize the dominant social norms and political goals". ${ }^{12}$ The reasoning underlying this hypothesis is much wider, since museums by definition share the past in two orders of presentation - knowledge and learning (history) and feeling and experience (aesthetics and politics). In new museums, however, the latter order seems to prevail over the first one. Whereas the order of knowledge and learning applies to the use of historical content in accordance with scientific requirements, the order of aesthetics and politics involves using symbols to work out a common repertoire for telling a story about the past. Since the past is attributable to a wide audience, it appears attractive mainly to them, a fact that is thriftily exploited by politicians and entrepreneurs, who use the museum for identity and commercial purposes. In this order, the museum serves the purpose of disseminating knowledge about the past, and, as Maria Popczyk observes, constitutes "a medium for exploring the world". ${ }^{13}$ Therefore, it fulfils a more general role as "a vehicle of meanings", where, because of cognitive needs, the collecting of "a certain class of objects leads to the aesthetic enrichment of the subject functions of what

${ }^{8}$ ZIĘBIŃSKA-WITEK, Anna. Historia w muzeach. Studium eksposycji Holocaustu [History in Museums. Study of the Holocaust Exhibition]. Lublin: UMCS, 2011, pp. 25-32; PIOTROWSKI, Piotr. Auschwitz versus Auschwitz. In: „Pro Memoria”, 2004/20, pp. 14-15.

${ }^{9}$ KORZENIEWSKI, Bartosz. Medializacja i mediatyzacja pamięci - nośniki pamięci i ich rola w kształtowaniu pamięci przeszłości, [Medialisation and Mediatisation of Memory - Storage Media and Their Role in Shaping the Memory of the Past]. In: „Kultura Wspótçesna” 2007/ 3, p. 9.

${ }^{10}$ MAYRAND, Pierre. The New Museology Proclaimed. In: „Museum”, 1985/148, p. 201 quoted by ZIĘBIŃSKAWITEK, Muzealizacja komunizmu..., p. 29.

${ }^{11}$ ZIĘBINSKKA-WITEK, Muzealizacja komunizmu..., p. 29.

12 ZIĘBIŃSKA-WITEK, Muzealizacja komuniżmu..., p. 30.

${ }_{13}$ SKÓRZYŃSKA, Muzeum historyczne: teatr - widowisko, aktor...p. 89; POPCZYK, Estetyczne pržestrzenie ekspozycii murealnych..., p. 26. 
is being gathered". ${ }^{14}$ What is more, through this aesthetic intervention, museums achieve the political goal of labelling the exposed objects in relation to the creation/selection of the form of presentation/representation. The selection relates to what, how, where, when, by whom, and to whom an object is being exposed-a selection inaugurating "a research activity aimed at creating a new type of knowledge about the past", ${ }^{15}$ in its new, and post-introductory functions. Perceived in this way, museums straddle the borders between science and art, history and memory, knowledge and identity, writing and image, and thought, imagination, and experience; in other words, between the temple of knowledge and a spectacle of the past. ${ }^{16}$ This is why Anna Ziębińska-Witek calls "the act of creating a museum exposition" an "act of creating a new meaning, a new understanding, a new interpretation, or a new world that has never really existed". ${ }^{17}$ And she names social actors, including institutional entities, that are responsible for such acts of creation. Among them are curators, whom she refers to as "creators of a reality that can be called 'a negotiated reality", and designers, "who deal with the visual aspect" of exhibitions; there are also patrons and sponsors, including the state and its agendas responsible for historical policy. "Relevant government factors", Ziębińska-Witek writes, "usually have a dominating impact on interpretation from a political point of view, and that impact tends to mystify rather than explain the relations between the past and the present, to secure rather than question the status quo". ${ }^{19}$ So where are the historians? When it comes to the musealisation of communism, historians are frequently found playing a subservient role towards patrons, curators, and designers, or have no role at all, especially if they do not acquiesce to subservience.

The complexity of contemporary museum practices, combined with the complex nature of contemporaries' approaches to communism, requires research methods and tools that are aptly selected and applied in methodological and methodical terms. Ziębińska-Witek has done just that by referring in her research on museums of communism to the analysis of visual discourse (Gillian Rose) and to a collective case study (Robert E. Stake), explaining that she was mainly interested in "the area of producing meanings by specific representations" of the past in a museum in their four dimensions: "technological, compositional, content-related, and worldview". ${ }^{20}$ The analysis of these dimensions of the presentation of communism allowed the author of Musealisation... to structure the argument using three orders to present the communist past: an identity-heroic order, a Tyrtaean-martyrologic order, and a nostalgic order. By analysing the four dimensions of the way in which museums of communism functioned through the three orders of the presenting of communism, Ziębińska-Witek describes in detail how the museums studied by her function, and compares the practices of the musealisation of communism in Poland with similar practices in other countries in Central and Eastern Europe,

\footnotetext{
${ }^{14}$ POPCZYK, Estetyczne przestrzenie eksposycii muzealnych..., p. 20.

${ }^{15}$ SKÓRZYŃSKA, Muzeum historyczne: teatr - widowisko, aktor...p. 90; POPCZYK, Estetyczne przestrzenie eksposycji muzealnych..., p. 20.

${ }^{16}$ SKÓRZYNSSKA, Widowiska pržesz̧łości...”. See more: Inscenizacje pamięci [Staging Memory]. Eds. Skórzyńska I., Lavrence Ch., Pépin C., Poznań: Wydawnictwo Poznańskie, 2007.

17 ZIĘBIŃSKA-WITEK, Murealizacja komunizmu..., p. 30.

18 ZIĘBIŃSKA-WITEK, Muzealizacja komuniżmu..., p. 30.

19 ZIĘBIŃSKA-WITEK, Muzealizacja komunižmu..., p. 30.

${ }^{20}$ ROSE, Gillian. Interpretacja materiałów wizualnych. Krytyczna metodologia badań nad wizualnościa [Interpretation of Visual Materials: Critical Methodology of Research on Visuality]. Warsaw: Wydawnictwo Naukowe PWN, 2010, pp. 174175; STAKE, Robert, E. Jakościowe stadium praypadku. In: Metody badań jakościowych, vol 1. Eds. Norman K. Denzin, Yvonna S. Lincoln. Warsaw: Wydawnictwo Naukowe PWN, 2010, pp. 623-654 qoted by ZIĘBIŃSKA-WITEK, Muzealizacja komunizmu..., p. 32.
} 
in terms of what they exhibit and how they exhibit it, what they do not exhibit and why they do not exhibit it, and how all this affects our knowledge about the past and our identity.

\section{Musealisation of Communism: (De)constructions}

Anna Ziębińska-Witek begins her critical review of selected museums of communism from the heroic-identity order, arguing that the presence of this type of musealisation is due to the fact that

post-communist countries are in a particularly difficult situation, since, apart from ... threats characteristic of the globalisation age, they must redefine their identity, define themselves in comparison to others, establish satisfying relations with the "old" members of the European Union, and overcome complexes and a feeling of inferiority; all this makes them prone to reach out to the national model in museums. ${ }^{21}$

This national model the presenting of the communist past, as Ziębińska-Witek shows, just like the language used to describe it, was derived (in the case of Poland) from the romantic mythology of the struggle for independence in its relations with the insurgent ethos and readiness of Polish patriots to sacrifice their lives for their homeland. This model, in her opinion, dominated the two museum-based communism-related narratives studied by her in Poland, namely those of the Museum of the June 1956 Uprising in Poznan, and the European Solidarity Centre in Gdańsk (ESC).

The Poznań and Gdańsk museums of communism are characterised by a constant tendency, the author writes, to nationalise a revolt of the nation by writing it into the romantic framing of uprising in the Poles' struggles for independence. For me this musealisation means that the problem of workers and classes, and the problem of an alliance of workers, the intelligentsia, and the church are all put on the back burner, and the line of political divisions drawn in museums applies only to the conflict between the authorities and the nation, where the nation is represented by heroes fighting for independence. Hence, the object of musealisation in both Poznań and Gdańsk is the national community, whose energy, as Ziębińska-Witek proves by referring to Maria Janion and Jadwiga Staniszkis, began to run low along with the transformation in Poland, when a certain "historical cycle" related to the fight for independence in the name of values that were common for all Poles came to an end (Janion). These remembered values and underlying community "return" in the museums in Poznań and Gdańsk?. ${ }^{22}$

In the case of the ESC, the aim of this solution is the positive image of Poles outside, while in the Museum of the June 1956 Uprising in Poznan it is also the desire of Poznanians to incorporate the history of their "rebellious city" into the heroic-identity "imaginarium" that is common to all Poles. But here Ziębińska-Witek observes that the identity-heroic trend, although promoting Poles in their positively assessed uniqueness, additionally smothers all else that was not so unambiguously positive, including the complex relationship between the citizens and the people's state, one that was based not only on heroism and fighting against the state, but also on an ambivalent attitude toward the state. This not only concerns resistance, but also acceptance of state rule, that is, on adapting in exchange for the leading of a normal life, where a majority

\footnotetext{
${ }^{21}$ ZIĘBIŃSKA-WITEK, Murealizacja komunižmu..., p. 44.

${ }^{22}$ JANION, Maria. Zmierzch paradygmatu [The Twilight of the Paradigm]. In: http://biblioteka.kijowski.pl/janion\%20 maria/co\%20prze\%BFy\%B3e\%9C.pdf (access: 10.05.2017); STANISZKIS, Jadwiga. Antropologia władsy. Mięzy traktatem lizbonskim a krysysem [Anthropology of Power: Between the Lisbon Treaty and the Crisis]. Warsaw: Prószyński i S-ka, p. 186, quoted by ZIĘBIŃSKA-WITEK, Muzealizacja komunizmu..., p. 43-45.
} 
of Poles lived according to the conditions dictated by the people's state. ${ }^{23}$

The Polish versions of the musealisation of communism in the identity-heroic trend are accompanied by the analyses of other CEE museums, including the House of Terror (Terror Háza) in Budapest and the museums of occupation in Riga and Tallinn. What do these museums and their expositions have in common? Well, as shown by Ziębińska-Witek, this positive auto-presentation of the national community (both within the community and outside it), which usually involves blowing the heroic acts of national heroes, the opponents of communism, out of proportion while avoiding the exhibition of individuals and events from the past that do not fit into this positive national order of presentation.

Contrary to in Poland, however, as Ziębińska-Witek notes, the situation in the museums in the Baltic States and Hungary is more complicated. In these countries, communism is more closely linked to Nazism, and the fight against communists overshadows collaboration with the Germans. That is why Terror Háza in Budapest presents, primarily, the Hungarians' fight against communists, and the exposition thus excludes content that is undesirable and inconvenient for Hungarians... The image created indicates that Hungarians were the victims of two systems rather than active perpetrators serving one or even both of these systems. This becomes clear in one part of the exhibition, where two uniforms-one of a Nazi and one a Soviet soldier-placed on a revolving platform suggest a simple replacement of one occupation for another one. ${ }^{24}$

In this sense, Terror Háza's presentation is similar, as Ziębińska-Witek shows, to the musealisation of communism in Latvia and Estonia, where the museums' narratives strongly underline the dual occupation and focus mainly on the victims, in particular the victims of Soviet occupation, and the heroes fighting the occupants. ${ }^{25}$ The exposition in the Riga museum (which is currently undergoing restoration) even covers the history of three occupations: the Soviet occupation between 1940 and 1941, the German occupation between 1941 and 1944, and the subsequent Soviet occupation between 1944 and 1991. ${ }^{26}$ These three periods of occupation were presented, however, through the criminality of totalitarian regimes, particularly the Soviet regime, and through the heroism and sacrifice of the Latvians in their struggle for independence. Thus, in Riga, similarly to in Budapest, a thorough, critical narrative on collaboration with the Germans is left out. It is evident that the museum in Riga had to address the problem of Soviet totalitarianism, but according to the Russian minority in Latvia, the Soviet occupation was presented erroneously as being equally horrific to the German one. This determined the fate of the Museum of Occupations, which was initially private and much more independent but which lost this independence when it was put under the supervision of the Latvian parliament.

The main axis of the dispute was the use of the term "occupation" in reference to the Soviet presence in Latvia after 1944. According to those against using this term, the expression "unlawful change of regime" would be more appropriate. The change would entail a complete restructuring of the exhibition ${ }^{27}$ and eventually the dispute ended with the museum being closed down. In return, one of the public buildings in Riga staged a temporary exhibition on the understanding of the occupation considering the differing experiences of the Soviet

\footnotetext{
${ }^{23}$ ZIĘBIŃSKA-WITEK, Muz̨ealizacja komunizฺmu..., pp. 45 \& next.

24 ZIĘBIŃSKA-WITEK, Muzealizacja komunizmu..., p. 72.

${ }^{25}$ ZIĘBIŃSKA-WITEK, Muzealizacja komunizmu..., p. 82.

${ }^{26}$ ZIĘBIŃSKA-WITEK, Muzealizacja komunizmu..., p. 82-84.

27 ZIĘBIŃSKA-WITEK, Muzealizacja komunizmu..., p. 85.
} 
presence in Latvia, Estonia, and Lithuania compared to in other CEE countries, and particularly in Western Europe, where communism remained outside the sphere of direct experience. Nevertheless, a branch of the Museum of Occupations in Riga located in the former KGB headquarters, which also used to house a Soviet prison, is still accessible. "Double occupation" is also referred to in the National Museum of Latvian History in the section dedicated to the most recent history. ${ }^{28}$ The Museum of Occupations in Tallinn, similarly to the museum in Riga, was opened through private initiative, by Olga Kistler-Ritso, an emigrant who established a foundation for this purpose. ${ }^{29}$ The permanent exhibition in the Tallinn museum was prepared, as the author of Musealisation... claims, with the close cooperation of Estonian historians. However, this does not change the fact that the exhibition is similarly misleading to the one in Riga. It maintains the same chronological framing, relating to the aforementioned three occupations Soviet (1940-41), German (1941-44), and again Soviet (1944-91). Additionally, it includes the Holocaust, the history of which, in a manner similar as for Hungarians, casts a shadow over Lithuanians, Latvians, and Estonians. In Tallinn, asserts Ziębińska-Witek, the Holocaust experience is parallel, at least on the level of the symbolism used (concrete suitcases outside the entrance to the museum), to the Gulag experience. ${ }^{30}$ Hence, in principle, Nazism and Communism stand in the same line of terror as regimes that deprived the Baltic States of their independence, a deprivation that eventually triggered their resistance. Yet the museum says little or nothing about submission to these regimes, not to mention the "asphyxiation" by these regimes.

By analysing and interpreting the selected identity-heroic museums of communism, Ziębińska-Witek draws our attention to the strategic goal underlying their establishment- the production of a national brand. ${ }^{31}$ In the museums of communism this national branding involves raising their fights and victories over communism to the level of myth, where free nations are established; furthermore, the more the authors conform to this convention of a narrative museum, the more persuasive those narratives become. The underlying source of this convention, dating back to the 1980s, was a reformation movement aimed at transforming/funding museums, and pivoted between the perspectives of the actions of specialists (historians, designers, and educators) and the audience, the emphasis being shifted to the latter, they being invited to participate in the creation (participation, performance) of the museum narrative. This entailed significant changes in museum productions, including undesirable changes, such as the creating of high-tech or narrative museums, where the former, instead of stimulating participation, in many instances limited the audience's activities to the effective technical operation of the exposition, and the latter, instead of inducing individual interpretation, closed the past via ready-made stories.

If the musealisation of communism in the identity-heroic trend was to be considered a call for values, then the musealisation in the martyrologic-Tyrtaean trend is, as Anna Ziębińska-Witek observes, a call for justice for the martyr-victims of the regime. ${ }^{32}$ This is how the contemporary deal with the memory of defeat, doing justice to those who died as heroes or martyrs for a lost or bygone cause. The call for justice, as the author of Musealisation... indicates, through references to Aleida Assmann, is also associated with the sustaining of claims

\footnotetext{
${ }^{28}$ ZIĘBIŃSKA-WITEK, Muzealizacja komunižmu..., p. 87.

${ }^{29}$ ZIĘBIŃSKA-WITEK, Murealizacja komunizmu..., p. 88.

${ }^{30}$ ZIĘBIŃSKA-WITEK, Murealizacja komunizmu..., pp. 89-90.

${ }^{31}$ ZIĘBIŃSKA-WITEK, Muzealizacja komunizmu..., pp. 62-63.

32 ZIĘBIŃSKA-WITEK, Muzealizacja komuniżmu..., pp. 61.
} 
for recognition and the right to revenge, reflected in the pathos accompanying exhibitions in the martyrologic-Tyrtaean order. ${ }^{33}$ Many museums of this kind, as Ziębińska-Witek illustrates, relate directly to the tradition of the Halls of Memory or prison-type museums. Most of them are autotelic and refer to "a single event ..., historical occurrence ..., person-fighter ... and martyr". ${ }^{34}$

They also fit into a group of "real death" museums, which Ziębińska-Witek addresses in detail in her works on the Holocaust. "In accordance with this concept, the most effective and convincing representations of the past combine the power of a real object, real place, and real person". ${ }^{35}$

This is how the Hall of Memory of the "Wujek" Coal Mine functions, where the story of the coal mine told in situ is linked to the dramatic events of the pacifying of the mine's workers on the first days of martial law in Poland. The exposition in the hall thus links specific victims to the history of the mine, the regional history, and the national history, fitting the victims into the order of national martyrdom in the fight for independence. That is why, according to Ziębińska-Witek, the memory of the victims of the pacification of the "Wujek" mine has been made concrete and sacred, while the perpetrators form "an impersonal, yet 'driving' force, that one must temporarily submit to". ${ }^{36}$

The situation is different in the Warsaw Hall of Memory of the Victims of Communist Terror and in the Hall of Memory of Communist Terror in Tomaszów Lubelski, where "the aesthetics of the exposition is different, and the symbolic punishment of the perpetrators is a strongly accented element". ${ }^{37}$ Otherwise, both these memory halls have the same goal of staging the victimisation of the victims to sanctify them in the place where they suffered and died. A common feature of these museums, as Ziębińska-Witek writes, is their cramped claustrophobic climate, achieved by locating them in basements, dark corridors, interrogation rooms, or prison cells, and their "selective authenticity" based on the combining of artefacts with their staging and simulations. These museums present two types of victims. Some are specific individuals who we know by name and whose martyr biographies we explore, while others are generic and unbranded, elusive, as if incidental, referred to in the museum not for their own sake, but to find "the mechanisms that led to their crimes". ${ }^{38}$

Similarly to the identity-heroic trend, the martyrologic-Tyrtaean musealisation involves a complex process of the nationalising of the victims-which sometimes takes the form, as Ziębińska-Witek notes, of a "sacrificial nationalism" with a tendency towards national megalomania-typical of such presentations. ${ }^{39}$

Among the Polish museums from the martyrologic-Tyrtaean order, the author of Musealisation... mentions the Father Jerzy Popiełuszko Museum located in the basement of Saint Stanisław Kostka Church in the Warsaw district of Żoliborz, mainly because of its uniquely hagiographic nature. The church's being the location of the museum has a double signifi-

\footnotetext{
33 ZIĘBIŃSKA-WITEK, Muzealizacja komunizmu..., pp. 113-115.

34 ASSMANN, Aleida. From Canon and Archive. In: The Collective Memory Reader. Eds. J. K. Olick, V. VinitzkySeroussi, D. Levy. Oxford: Oxford University Press, 2011, p. 50 quoted by ZIĘBIŃSKA-WITEK, Muz̧ealizacja komunizmu..., pp. 113-115.

${ }^{35}$ ZIĘBIŃSKA-WITEK, Muzealizacja komunizฺnu..., p. 116.

${ }^{36}$ ZIEBIŃSKA-WITEK, Muqealizacja komunizmu..., p. 121.

${ }^{37}$ ZIĘBIŃSKA-WITEK, Muzealizacja komunizmu ..., p. 121.

38 ZIĘBIŃSKA-WITEK, Murealizacja komunizmu..., pp. 124-125.

${ }^{39}$ ZIĘBIŃSKA-WITEK, Mužealizacja komuniżmu..., pp. 125-126.
} 
cance-as the place where Father Jerzy Popiełuszko celebrated mass for the homeland, and also as a materialised sacrum, which both draws on and gives martyrs sacred attributes. ${ }^{40}$ In the case of the Father Jerzy Popiełuszko Museum, this sacredness also comes from other sources: there is the priest, a martyr, and his catacomb museum; the sacredness of the church founded on a century-long practice of raising martyrdom to the rank of the highest sacrifice; and the exposition that culminates in the "Golgota" where, apart from other elements, there are trees (today wood) from the place where Father Popiełuszko was beaten and tortured. Ziębińska-Witek refers to these trees as "inhuman witnesses of history", alluding to the ongoing debates on witnesses to the Holocaust, in the context of the deaths of those who could give witness to it, and to the importance of an object as evidence of their existence and death. ${ }^{41}$ In addition, as aptly noticed by the author of Musealisation..., the grave of the priest-martyr is located near the church housing the museum dedicated to Father Jerzy Popiełuszko, meaning that the museum and its exhibitions can be viewed as a place of pilgrimage. However, the "exhibition fails to mention ... that Popiełuszko was not the only priest persecuted and murdered during communist times. Instead, the exhibition fills this void by highlighting the incontrovertible divine intervention and divine providence" of this event. ${ }^{42}$

Everything mentioned previously, that is, sacrificial nationalism and the tendency towards a hagiographic presentation of the victims of communism, can also be found in other Central and Eastern European museums, including in Romania, where, especially after 2006, efforts were taken to work out a settlement on museum narration. These efforts are reflected in the new expositions in old museums (e.g. the Museum of Romanian History), and in newly established museums (e.g. the Museum of the Romanian Farmer), where communism is only one of many themes in the permanent exposition. There is, however, a memorial in Romania dedicated to the victims of communism. Brought into being a Romanian dissident, Ana Blandiana, with the cooperation of Romulus Rusan, the memorial is located in a former prison in Sighet. Although this museum refers to several dimensions of communism in Romania in the form of an extensive story, special emphasis is put on the Romanian anti-communist movement and its victims, including those buried in the prison cemetery whose remains could not be identified, despite archaeological studies, but who deserve commemoration, even more so because the Communists were highly successful in obliterating traces of martyrdom and evidence of their own crimes. This is why Sighet Memorial stages these "relicts" that commemorate the victims of communism with pietism. The memory of the victims has also been marked as a necropolis and monumental structure dominated by coniferous trees rising from the ashes of the murdered martyrs. ${ }^{43}$

Ziębińska-Witek places the Genocide Victims Museum in Vilnius among the martyrologic-Tyrtaean museums, where, similarly to the museums of occupation in Riga and Tallinn, communism is equated with $\mathrm{Nazism}^{44}$ and the entire exposition refers mainly to Lithuanian martyrs fighting for independence. This is the reason the visit to the Vilnius museum ends in

\footnotetext{
${ }^{40}$ ZIĘBIŃSKA-WITEK, Muzealizacja komunizmu..., pp. 131-132.

${ }^{41}$ AGAMBEN, Giorgio. Co zostaje z. Auschwitz [What Remains of Auschwitz]. Warszawa: Sic!, 2008, p. 33, quoted by ZIĘBIŃSKA-WITEK, Muzealizacja komunižmu..., pp. 138-139.

42 ZIĘBIŃSKA-WITEK, Muzealizacja komuniżmu..., p. 141.

${ }^{43}$ DOBRE, Claudia Florentina. Communism at the Museum: Staging Memory at the Sighet Memorial. In: Performing the Past: Post-Communist Poland and Romania. Poznań: Instytut Historii 2014. Eds. I. Skórzyńska, Ch. Lavrence, p. 40, quoted by ZIĘBIŃSKA-WITEK, Muz̨ealizacja komunizmu..., p. 154. Dobre: 2014, p. 40)

${ }^{44}$ ZIĘBIŃSKA-WITEK, Mužealizacja komunizmu..., pp. 156-157.
} 
the Execution Hall, where, walking on a plexiglass floor, the visitors can see the victims' private belongings below. For Ziębińska-Witek, the Execution Hall is a clear and deliberate reference to the "Central Sauna" in Auschwitz-Birkenau II, where boards also covered the floors. ${ }^{45}$

Anna Ziębińska-Witek compares the martyrologic museums of communism, which place strong emphases on the martyrdom of the victims of this regime, to the few ironic narratives concerning communism. Their relation to the martyrologic-Tyrtaean trend stems from the fact that these ironic stagings/narratives/performances "reside" in historical places, such as the STASI Museum in Berlin and Dresden or the exhibition on the 23rd floor of the Viru Hotel in Tallinn. All these places once housed the KGB and STASI, which, either directly or indirectly, caused many people great suffering, depriving them of their freedom and sometimes their life. Here, however, it is not about the victims, but about the perpetrators, not about the solemnity of martyrdom, but about condemning those that caused it. Ziębińska-Witek thus refers to these museums as expositions of "the everyday life of the intelligence agency". This life is presented au rebours, as a machine of repression, which, however almighty it was in the communist context, and however much suffering it caused to so many helpless victims, still failed abysmally in its fight against the people. ${ }^{46}$

Referring to the identity-heroic and martyrologic-Tyrtaean trends in the musealisation of communism, Ziębińska-Witek writes about the enormous emotional toll the exposition takes, especially in the case of the latter trend, and also accentuates the emotive experiences of the audience. And these are special experiences, connected with the exposition of both heroism and suffering, the moral argumenta of the victims that today make it possible to take symbolic revenge on the torturers. Whether there is room for history and for distance from and a critical analysis of the experience of communism in the politics of aesthetics remains an open question since communism, and here I move to the last part of the book by Ziębińska-Witek, is also quite abundantly represented in the form of nostalgic exhibitions and museums.

In reference to nostalgia as a framework for presenting communism, the author discusses an array of exhibition practices for which the sentimentalisation and carnivalisation of communism act as a common denominator. Carnivalisation, for example, is represented by the protagonist's practices, as described by Ziębińska-Witek, as a fight of sorts against communist monuments, which, in the course of cleansing public space of the hated symbols, took shape, most notably in the early 1990s, via street festivities, when citizens, humiliated by the authorities, often spontaneously meted out symbolic punishment to the statues of their torturers. However, the further away from 1989 one moves, the more these practices incorporated politics (decommunisation), and the less spontaneous they thus became, dampening the spirit of joyfully exorcising revolutionary leaders and their historical accomplices. Along with decommunisation came complications, depending on what the monument symbolised. The monument of Russian soldiers, for example, hid the ashes of the fallen soldiers; the Palace of Culture and Science in Warsaw is not only an inexorable element of the urban fabric, but also a testimony of enslavement, and its presence, according to many, should act as a warning for posterity. ${ }^{47}$

The nostalgic trend of communism musealisation is also, as Ziębińska-Witek writes, a matter of a forgone generational experience. This function, according to the author, is fulfilled

\footnotetext{
${ }^{45}$ ZIĘBIŃSKA-WITEK, Muzealizacja komunizmu..., pp. 159-161.

46 ZIĘBIŃSKA-WITEK, Muzealizacja komunizmu..., p. 84.

47 ZIĘBIŃSKA-WITEK, Muzealizacja komunizmu..., pp. 183-225.
} 
by two private museums of the People's Republic of Poland, one in Warsaw and one in Ruda Ślaska, and by the Museum of the GDR and Trabant in Berlin. Interestingly, the founding of these museums was driven not so much by the everydayness of communism, but by the nostalgia for that everydayness. Hence, the expositions in these museums were designed to reflect how people still/already remember communism rather than reflecting on what it was really like. This approach results in two possible interpretation tactics. One refers to the witnesses of history who can still critically refer to these museum reservoirs of memories, and the other one refers to their successors, for whom this nostalgic communism can be a potential source of entertainment. ${ }^{48}$

In this context, the two other museums described by the author of Musealisation ... present a completely different light. The Berlin Wall Museum, where the cognitive dimension of a dispersed exposition seems to continuously win with an attractive form of presentation, is clearly imbued with nostalgia for communism. In the Museum of the State Agricultural Farm in Bolegorzyn (Drawsko County), nostalgia applies not so much to life in a socialist country as to the security that State Agricultural Farms provided to Polish farm workers in communist Poland, which farmers lost, many irrecoverably, when political change swept through the transformation.

According to Ziębińska-Witek, the establishment of the Museum of the State Agricultural Farm was a local and bottom-up driven initiative, carried out under the countrywide slogan "Let's save [exhibits] from oblivion-time passes so quickly!" 49 . Hence, the museum became both a place for the gathering of post-state agriculture farm mementoes, not only from the region but also from all over the country, and a museum of objects. The objects (artefacts) are organised in three thematic blocks that refer to the past life in state agricultural farms, the past life in the People's Republic of Poland, and to the past life of the inhabitants of Drawsko, that is, local Germans. Who, then, is this museum for? In an attempt to answer this question, Ziębińska-Witek refers to Bożena Kulicz, the initiator of the museum, who mentioned both the absence of a common history and memory amongst the inhabitants of the former state agricultural farms and, furthermore, the absence of a continued memory in posterity; a majority of those from the more degraded areas emigrated from these lands in the transformation period. The museum was meant to fill this gap by calling for recognition of the past by the inhabitants of communist agri-towns, marginalised after 1989 as part of a common foundation myth. If there was a place for heroes who fought communism and for martyrs of communism, there should also be a place for common people, also including for those who, in a sense, were beneficiaries of this communism. ${ }^{50}$

\section{Conclusions}

When one year ago I was preparing a short review of Anna Ziębińska-Witek's book for The Polish Review $w^{51}$, I could not share with readers all the conclusions particularly important from the point of view of the inhabitants of Central and Eastern Europe, who are facing not only the heritage, but also the burden of communism. This was not only because Ziębińska-Witek

\footnotetext{
48 ZIĘBIŃSKA-WITEK, Muzealizacja komuniz̧mu..., pp. 183-225.

49 ZIĘBIŃSKA-WITEK, Muzealizacja komunižmu..., p. 192.

${ }^{50}$ ZIĘBIŃSKA-WITEK, Murealizacja komunižmu..., pp. 174-175.

${ }^{51}$ SKÓRZYŃSKA, Izabela. Muzealizacja komunizmu w Polsce i Europie Środkowo - Wschodniej [Musealization of Communism in Poland and Central and Eastern Europe], by Anna Ziębińska-Witek, In: „The Polish Review” 2020/4, pp.107-109.
} 
has created a piece of work so rich in references to varied empirical material and so dense in interpretational terms that it was neither easy to deal with them nor, all the more, to disregard them, but also because we have still not had enough time to deal with communism, which to this day deeply influences our cultural, social, and political life and our sense of security. In this context, musealisations of communism serve, of course, at least to some extent, to consign it to the past. This is the reason why we historicise but also carnivalise, exorcise, sentimentalise, and so on, communism in museums, and this is the reason why we sacralise its victims and stigmatise its perpetrators. However, these are not practices from the realm of knowledge and cognition but rather of politics and aesthetics. This process which, then, is supposed to help us deal with communism - its musealisation — still maintains unbearable currency for its community of memory.

It would be unfair of me not to mention that Ziębińska-Witek also identifies the musealisation of communism as a potentially positive reservoir of historical knowledge and a source thanks to which we can "update" the community in terms of values. The notion that the author particularly draws our attention to, however, is the relationship between objects and their meaning in museums of communism. This relationship, she contends, remains in flux, as do the relationships between history and memory, politics and aesthetics, communism and its staging, and, going further, between the intention of the authors and the expectations of the audience, about whom, despite being the most important element in this equation, unfortunately, we still know relatively little. This is why the discussion on what communism has done with us and what its musealisations do with us still remains important, open, and inspirational.

\section{References}

KORZENIEWSKI BARTOSZ (2007). Medializacja i mediatyzacja pamięci - nośniki pamięci i ich rola w kształtowaniu pamięci przeszłości. In: Kultura Wspótczesna, 2007/3.

POPCZYK Maria (2008). Estetycz̨ne przestrzenie elespozycji muzealnych. Kraków: Universitas. ISBN: 97883-242-0888-3

SKÓRZYŃSKA, Izabela, LAVRENCE Christine, PEPIN Carl (eds.) (2007). Inscenizacje pamięci, Poznań: Wydawnictwo Poznańskie. ISBN 978-7177-83-577-2

SKÓRZYŃSKA, Izabela (2010), Widowiska przeszłłości. Alternatymne polityki pamięci 1989-2009. Poznań: Instytut Historii UAM. ISBN 978-83-89407-75-7

SKÓRZYŃSKA, Izabela (2014). Muzeum historyczne: teatr - widowisko, aktor - świadek. In: Historia Polski Od-nowa. Nowe narracje historii i muzealne reprezentacje przeszłości (eds.) R. Kostro, K. Wóycicki, M. Wysocki, Warsaw: Muzeum Historii Polski, ISBN 978-83-60642-93-1

SZPOCINSKI, Andrzej (2004). Tworzenie przestrzeni historycznej jako odpowiedź na nostalgię, Kultura Wspótczesna, 2004/1.

ZIĘBIŃSKA-WITEK, Anna (2011). Historia w muzeach. Studium ekspozycji Holocaustu. Lublin: UMCS. ISBN 978-83-7784-043-6

ZIĘBIŃSKA-WITEK, Anna (2018). Muzealizacja komunizmu w Polsce i Europie Środkowo Wschodniej. Lublin: UMCS. ISBN 1-341. 978-83-227-9149-3 